Ereky, K. (1926). British Patent no. 270,629.

Guyadeen, K. D. (I951). Trop. Agriculture, Trin., 28, 23 r.

Jackson, P. (1954). \%. Cons. int. Explor. Mer, 20, 167.

Kandiah, S. \& Koch, D. E. V. (1938), Agriculturalist, 90, 3.

Lugg, J. W. H. (1938). Biochem. F. 32, 2114.

Pal, P. R. \& Guha, B. C. (1953). Sci. \&5 Cult. 18, 597.

Pirie, N. W. (1952). Rep. Rothamst. exp. Sta. p. 173.

Pirie, N. W. (1955). In Modern Methods of Plant Analysis. Vol, 4, p. 23. [K. Paech \& M. V. Tracey, editors.] Heidelberg: Springer.

Raymond, W. D., Jojo, W. \& Nicodemus, Z. (194r). E. Afr. agric. F. 6, I 54 .

Reber, E. \& MacVicar, R. (1953). Agron. F. 45, I7.

Rouelle, H. M. (1773). F. Med. Chir. Pharm. 40, 59.

Takagi, M. (1950). Bull. Fac. Fish. Hokkaido, I, 35.

Teng-Yi Lo \& Chih-Hua Wu (1942). J. Chin. chem. Soc. 9, 108.

Wallace, L. R. (1955). Proc. Nutr. Soc. 14, 7.

Williams, P. N. (1953). Chem. Eீ Ind. p. $5^{82}$.

\title{
Some technological developments of importance in animal nutrition
}

\author{
By J. Duckworth, Rowett Research Institute, Bucksburn, Aberdeenshire
}

Adequately to review the technological translation of nutritional science into commercial practice is beyond the scope of a single communication. Attention must be restricted to a narrow field and the relationship between technology and protein provision has been selected.

This is no arbitrary choice. Most common energy sources are often too low in protein for productive purposes and must be supplemented to secure appropriate ratios of metabolizable energy to digestible protein. All protein-rich supplements are expensive, relative to the basic energy sources, and thus minimum feeding costs are realized only when supplements are added at the level that just satisfies the animal's needs. In practice, an excess must be added to provide a margin of safety and the greater the uncertainty about dietary protein the greater this margin must be.

This uncertainty has four major origins: variation in protein content among different batches of individual feeding-stuffs, variation in amino-acid composition within the total protein content, natural variation in protein digestibility, and variable effects of processing on protein quality, defined in terms of digestibility and of metabolic availability of certain important amino-acids of the digested protein. An independent source of uncertainty is variation in the metabolizable energy of feeding-stuffs, disturbing the nutritive ratio. Organizations sufficiently large to afford chemical analysis can eliminate uncertainties about the content of protein and metabolizable energy. The other uncertainties remain, except for those who, by animal trials, can identify sources of feeding-stuffs that are consistently or erratically inferior in protein quality, and thereafter avoid them. This does not necessarily remove them from the market but rather deflects them into hands that lack testing facilities. 
Research and technological development aim at reducing this uncertainty. Important features are studies of processing to obtain by-products of uniformly high protein value, of inheritance of desirable amino-acid levels in feed proteins, of synthetic production of amino-acids, and of applying nitrogenous fertilizers to raise the protein content of energy crops.

Hitherto, most effort has been concentrated on research in processing. Unfortunately it has not been uniformly pursued in all producing countries or with all protein concentrates. Least of all has any serious attempt been made to discriminate in technological development between what constitutes high protein value for ruminants and what constitutes high protein value for non-ruminants. Because of this irregularity in development an evaluation of technological achievements must begin with an examination of the kinds and sources of this country's protein concentrates.

\section{The supplies of home-produced and imported protein-rich by-products in the United} Kingdom, I 953 to 1955

No other nation of our size has the problem of making efficient rations for its livestock with feeding-stuffs so diverse and fluctuating in origin and kind. Nor is any other nation as dependent on the technological capacity of manufacturers abroad.

Animal by-products. Home-produced and imported meals increased about equally, making total supplies $33 \%$ greater in 1955 than in 1953 (Table I). Almost half the increase came from greater home production of meat meals, giving it greater importance in 1955 than in 1953 . Herring-meal supplies increased markedly owing to increased imports, home production falling. Supplies of fish meal increased by about $8 \%$ during the period, mainly through increased home production. Whaling by-products played a small part, decreasing relative to total supplies by 1955 .

Table I. Total, home-produced and imported United Kingdom supplies of animal by-products for the period from 1953 to 1955 , expressed as a percentage of the total 1953 supplies (229,228 tons)

\begin{tabular}{|c|c|c|c|c|c|c|c|c|c|}
\hline \multirow[b]{2}{*}{ By-product* } & \multicolumn{3}{|c|}{ Total supplies } & \multicolumn{3}{|c|}{ Home-produced } & \multicolumn{3}{|c|}{ Imported } \\
\hline & $\mathrm{x} 953$ & I954 & 1955 & I953 & 1954 & 1955 & 1953 & 1954 & 1955 \\
\hline Fish meals & $4 I \cdot I$ & $46 \cdot 2$ & $49 \cdot 3$ & $28 \cdot 3$ & $30 \cdot 0$ & $33 \cdot 9$ & 12.8 & $16 \cdot 2$ & $15 \cdot 4$ \\
\hline Herring meals & $21 \cdot 2$ & $25 \cdot 9$ & $29 \cdot 7$ & $8 \cdot \mathrm{I}$ & $6 \cdot 0$ & $5 \cdot 5$ & $13 \cdot 2$ & 19.9 & $24 \cdot 2$ \\
\hline Whale meals & II $\cdot 9$ & $14 \cdot 7$ & $13 \cdot 4$ & - & - & $\cdots$ & I I $\cdot 9$ & 14.7 & $13 \cdot 4$ \\
\hline Meat meals & $25 \cdot 8$ & $3 I \cdot 2$ & $40 \cdot 7$ & $15 \cdot 2$ & $26 \cdot 4$ & $29 \cdot 8$ & 10.5 & 4.8 & 10.9 \\
\hline Total & $100 \cdot 0$ & I I $8 \cdot 0$ & $133 \cdot I$ & $5 \mathrm{I} \cdot 6$ & $62 \cdot 4$ & $69 \cdot 2$ & $48 \cdot 4$ & $55 \cdot 6$ & 63.9 \\
\hline
\end{tabular}

* Fish meals include all made from non-fatty fish. Whale meals include all whale by-products. Meat meals include all meat by-products.

Great diversity of origin and wide fluctuations in amounts and kinds of animal by-products characterize the imports over the 3-year period (Table 2). Increased imports of herring meal from Norway and the replacement of meat meals by greater imports of herring meal from Denmark were accompanied by large increases in meat-meal imports from the U.S. Substantial imports of meat meals from the Argentine in 1953 were replaced by small imports of whale meals in 1954, and were 
almost nil in 1955. South and South-west (Portuguese) Africa together provided a large and steady supply of fish meal. The fall in imports from British whaling (probably factory ships) was partly offset by increased imports from the Falklands and elsewhere. Import statistics do not permit accurate identification of the origins of whaling products, which pass through diverse channels to the U.K.

Table 2. Supplies of animal by-products imported into the United Kingdom from different sources during the period from 1953 to 1955 , expressed as a percentage of the 1953 total imports (I I 1,007 tons)

\begin{tabular}{|c|c|c|c|c|}
\hline Source & $\begin{array}{l}\text { Major changes, } \\
\text { x } 955 \text { compared } \\
\text { with } 1953\end{array}$ & I953 & 1954 & 1955 \\
\hline Norway & + & $25.8 \mathrm{H} *$ & $39 \cdot 0 \mathrm{H}$ & $42.9 \mathrm{H}$ \\
\hline S. W. Africa & & $20.5 \mathrm{~F} *$ & I8.I F & $17.7 \mathrm{~F}$ \\
\hline British whaling & - & $12.7 \mathrm{~W}^{*}$ & $15.8 \mathrm{~W}$ & $8.2 \mathrm{~W}$ \\
\hline Argentine & - & $\mathrm{II} \cdot 4 \mathrm{M}^{*}$ & $3.6 \mathrm{~W}$ & $t$ \\
\hline Falklands & & $8.6 \mathrm{~W}$ & $10.2 \mathrm{~W}$ & II $\cdot 3 \mathrm{~W}$ \\
\hline S. Africa & & $4.7 \mathrm{~F}$ & II.4 F & $7 \cdot \mathrm{IF}$ \\
\hline Australia & - & $3.3 \mathrm{~W}$ & O.I M & + \\
\hline Denmark & + & $3 \cdot 2 \mathrm{M}$ & $2 \cdot 4 \mathrm{H}$ & $6.8 \mathrm{H}$ \\
\hline U.S.A. & + & $2.0 \mathrm{M}$ & $7.4 \mathrm{M}$ & $19.5 \mathrm{M}$ \\
\hline Belgium & & $1.9 \mathrm{M}$ & $0.4 \mathrm{M}$ & $0.4 \mathrm{M}$ \\
\hline Iceland & & $1.8 \mathrm{~F}$ & $2.6 \mathrm{~F}$ & 4. I F \\
\hline New Zealand & & $1.4 \mathrm{M}$ & $\mathrm{I} \cdot 2 \mathrm{M}$ & $\mathrm{I} \cdot 4 \mathrm{M}$ \\
\hline Uruguay & & $1.0 \mathrm{M}$ & Nil & $t$ \\
\hline Canada & & $0.7 \mathrm{~F}$ & I. I F & $2 \cdot 4 \mathrm{~F}$ \\
\hline Other countries $\ddagger$ & + & $\mathrm{I} \cdot \mathrm{O}$ & $I \cdot 4$ & IO.IW \\
\hline Total & & 100.0 & 114.7 & I $3 \mathrm{I} \cdot 9$ \\
\hline
\end{tabular}

$\mathrm{F}=$ fish meal $; \mathrm{H}=$ herring meal $\mathbf{M}=$ meat or meat-and-bone meal; $\mathrm{W}=$ whale meat or meat-andbone meal.

* Letter indicates the predominant kind of animal by-product imported during the year.

$\uparrow$ Trivial imports.

I Including, in order of decreasing importance, for the 3-year period: other Commonwealth countries, Holland, Peru, Paraguay, Chile, Pakistan, India, Faroes, Portugal, Italy, Tanganyika and Kenya, Basutoland, Azores and Madeira, W. Germany, French Morocco, Eire, Sweden, Cyprus, Malta, Channel Isles and others.

Oilseed by-products. Total supplies of oilseed meals fell in 1954, from the 1953 level, and rose sharply in 1955 (Table 3 ). The extra supplies in 1955 came entirely from greater imports of by-products, reflecting the increasing trend of countries abroad to process oilseeds. Within the total annual supply the pattern of kinds fluctuated greatly from year to year. From 1953 levels, total supplies of cottonseed, palm-kernel and sunflower-seed meals decreased sharply in 1954, a change that was partly offset by a large increase in groundnut-meal supplies and small increases in less common kinds. Relative to 1953 , the 1955 supplies of cottonseed, groundnut and soya-bean meals increased, but the supplies of palm-kernel and, particularly of sunflower-seed meals fell substantially. Over the 3-year period home production of soya-bean and linseed meals increased and of palm-kernel cake decreased, with erratic fluctuations in cottonseed, groundnut and copra processing. The greatest 
fluctuations were among imported meals: 1955 imports of cottonseed meals were at about twice the 1954 level, imports of groundnut meal at about twice, of soya-bean meal at about four times and of sunflower-seed meal at about a quarter of the 1953 levels.

Table 3. Total, home-produced and imported United Kingdom supplies of oilseed meals during the period from 1953 to 1955 , expressed as a percentage of the total 1953 supplies $(1,364,790$ tons $)$

\begin{tabular}{|c|c|c|c|c|c|c|c|c|c|}
\hline \multirow[b]{2}{*}{ Meal } & \multicolumn{3}{|c|}{ Total supplies } & \multicolumn{3}{|c|}{ Home-produced* } & \multicolumn{3}{|c|}{ Imported } \\
\hline & 1953 & 1954 & I955 & 1953 & 1954 & 1955 & 1953 & 1954 & 1955 \\
\hline Cottonseed & $25 \cdot 5$ & I 9.8 & 34.9 & $9 \cdot 8$ & 7.0 & 10.9 & 15.7 & 12.8 & $24 \cdot 0$ \\
\hline Groundnut & $22 \cdot 9$ & $29 \cdot 2$ & $28 \cdot 2$ & 14.8 & $16 \cdot 8$ & $12 \cdot 1$ & $8 \cdot 1$ & I $2 \cdot 4$ & $16 \cdot 1$ \\
\hline Palm kernel & $17 \cdot 5$ & $12 \cdot 0$ & 13.5 & $17 \cdot 5$ & $12 \cdot 0$ & $13 \cdot 5$ & - & - & - \\
\hline Sunflower & 12.9 & $4 \cdot 9$ & 3.0 & - & - & - & 12.9 & 4.9 & $3 \cdot 0$ \\
\hline Linseed & $8 \cdot 3$ & $9 \cdot 7$ & $7 \cdot 5$ & 0.5 & $1 \cdot 4$ & $2 \cdot 2$ & $7 \cdot 8$ & $8 \cdot 3$ & $5 \cdot 3$ \\
\hline Soya bean & $5 \cdot 4$ & $7 \cdot 3$ & 18.0 & $2 \cdot 5$ & $3 \cdot I$ & $6 \cdot 5$ & 2.9 & $4 \cdot 2$ & $11 \cdot 5$ \\
\hline Copra & $2 \cdot 9$ & $3 \cdot 4$ & $2 \cdot 2$ & $2 \cdot 9$ & $3 \cdot 4$ & $2 \cdot 2$ & - & - & - \\
\hline Rape & 0.8 & 0.8 & 0.8 & 0.6 & 0.3 & 0.2 & 0.2 & 0.5 & 0.6 \\
\hline Sesame & 0.7 & 0.4 & 0.2 & 0.7 & 0.4 & 0.2 & - & - & - \\
\hline Others & $3 \cdot I$ & $5 \cdot 0$ & $5 \cdot 3$ & 0.8 & $1 \cdot 2$ & 0.4 & $2 \cdot 3$ & 3.8 & $4 \cdot 9$ \\
\hline Total & $100 \cdot 0$ & $92 \cdot 5$ & I I 3.6 & $50 \cdot 1$ & $45 \cdot 6$ & $48 \cdot 2$ & $49 \cdot 9$ & $46 \cdot 9$ & $65 \cdot 4$ \\
\hline
\end{tabular}

* Calculated from oilseed import figures on the assumption that all meals contain about $5 \%$ oil.

The greatest changes in origin of imported oilseed meals were the return of Indian groundnut meal, the marked decrease in Argentinian sunflower-seed meal and the large increase in Canadian soya-bean meal (Table 4). Large decreases in cottonseed-meal supplies from Egypt and the Sudan were more than offset by increased imports from the U.S. and various smaller countries. Nigeria and French West Africa increased in importance as sources of groundnut meal, and Roumania became a more important source of sunflower-seed meal than the Argentine. Uruguay became a less important source of linseed meal than the Argentine.

The meaning of 'high protein value', applied to protein-rich concentrates

It is generally agreed that the processing of a material that yields a protein concentrate as a by-product should be adjusted so that the nutritive value of the protein in the by-product is as high as is compatible with the overriding demands imposed by manufacturing the main product. Unfortunately, the term 'high nutritive value' is often used without definition of the species to be fed or the nature of the diet in which the concentrate is to be incorporated although, without these, the term is meaningless. Too frequently the experimental basis for assigning the term is no more than the estimation of the biological value or of the capacity of the protein to support growth when fed as the sole nitrogen source in synthetic diets, and, valuable though these assessments of nutritive value are, they yield knowledge that is remote from application in practical feeding.

The essentials for high nutritive value of protein for ruminanats are becoming better understood. Since part of the nitrogen of the diet is converted to microbial 
Table 4. Supplies of oilseed cakes and meals imported into the United Kingdom from different sources during the period from 1953 to $\mathrm{I} 955$, expressed as a percentage of the total 1953 imports (681,058 tons)

\begin{tabular}{|c|c|c|c|c|}
\hline Source & $\begin{array}{l}\text { Major changes } \\
\text { x955 compared } \\
\text { with } 1953\end{array}$ & I953 & I954 & 1955 \\
\hline Argentine & - & $39 \cdot 6 \mathrm{SF}^{*}$ & $22.8 \mathrm{~L}$ & $7.8 \mathrm{~L}$ \\
\hline Canada & + & $8.7 \mathrm{SB} *$ & ro. $6 \mathrm{SB}$ & $25.6 \mathrm{SB}$ \\
\hline Egypt & - & $8.6 \mathrm{C}$ & $0.4 \mathrm{~L}$ & $2 \cdot 4 \mathrm{C}$ \\
\hline U.S.A. & + & $8 \cdot 2 \mathrm{C}$ & $6.4 \mathrm{C}$ & $18.6 \mathrm{C}$ \\
\hline Burma & & $6 \cdot 1 \mathrm{G} *$ & $8.6 \mathrm{G}$ & $9.2 \mathrm{G}$ \\
\hline Uruguay & & $5.5 \mathrm{~L} *$ & $4 \cdot I \mathrm{~L}$ & I.OL \\
\hline Uganda & & $4 \cdot 2 \mathrm{C}$ & $3 \cdot 4 \mathrm{C}$ & $5 \cdot 4 \mathrm{C}$ \\
\hline Pakistan & & $3.6 \mathrm{C}$ & $3 \cdot 2 \mathrm{C}$ & $6 \cdot 4 \mathrm{C}$ \\
\hline Sudan & & $2.7 \mathrm{C}$ & $2.0 \mathrm{C}$ & $\mathrm{I} \cdot 4 \mathrm{C}$ \\
\hline Nigeria & & $2 \cdot 3 \mathrm{G}$ & $5 \cdot 5 \mathrm{G}$ & $5.0 \mathrm{G}$ \\
\hline Kenya & & $1.4 \mathrm{C}$ & $2.5 \mathrm{C}$ & $2 \cdot 3 \mathrm{C}$ \\
\hline Syria & & $\mathrm{I} \cdot 2 \mathrm{C}$ & $\mathrm{I} \cdot \mathrm{I} \mathrm{C}$ & $\mathrm{I} \cdot 0 \mathrm{C}$ \\
\hline Tanganyika & & $\mathrm{I} \cdot \mathrm{OC}$ & $\mathrm{I} \cdot 5 \mathrm{C}$ & $1.9 \mathrm{C}$ \\
\hline Peru & & $0.8 \mathrm{C}$ & $1.0 \mathrm{C}$ & $2 \cdot 3 \mathrm{C}$ \\
\hline Roumania & & $0.3 \mathrm{R} *$ & I.OSF & $3.7 \mathrm{SF}$ \\
\hline Germany & & $0.3 \mathrm{G}$ & $\mathrm{I} \cdot 7 \mathrm{C}$ & $\mathrm{I} \cdot 2 \mathrm{C}$ \\
\hline Mexico & & $0.2 \mathrm{C}$ & $\mathrm{I} .0 \mathrm{C}$ & $0.5 \mathrm{C}$ \\
\hline French West Africa & & $0.1 \mathrm{G}$ & $3 \cdot 1 \mathrm{G}$ & $3 \cdot 4 \mathrm{G}$ \\
\hline Iran & & $t$ & + & $3.0 \mathrm{C}$ \\
\hline India & + & Nil & $0.6 \mathrm{G}$ & $15 \cdot 1 \mathrm{G}$ \\
\hline France & & Nil & $7 \cdot 2 \mathrm{G}$ & $3 \cdot 6$ \\
\hline Other countries $\ddagger$ & & $5 \cdot 2 \mathrm{SF}$ & $6 \cdot 3 \mathrm{C}$ & $10.1 \mathrm{C}$ \\
\hline Total & + & 100 & $94 \cdot 0$ & 130.9 \\
\hline
\end{tabular}

$\mathrm{C}=$ cottonseed $; \mathrm{G}=$ groundnut $\mathrm{L}=$ linseed $; \mathrm{R}=$ rapeseed $\mathrm{SB}=$ soya bean; $\mathrm{SF}=$ sunflower.

* Letters indicate the predominant kind of oilcake or meal imported during the year.

+ Trivial imports.

Including, in order of decreasing importance, for the 3-year period: S. Africa, Portuguese E. Africa, Lebanon, Bulgaria, Dominica, Yugoslavia, Portugal, Gambia, Italy, Haiti, Turkey, Denmark, Sweden, China, Morocco, Ethiopia, Algeria, Ecuador, Holland, Australia, Eire, Indonesia, and others.

protein in the rumen the maximum nutritive value attainable will be the combination of residual unchanged dietary protein and microbial protein yielding, on digestion, the content of critical amino-acids most favourable to the productive state of the host. It is known that proteins of high solubility in rumen fluid are rapidly and extensively broken down by microbial action to yield ammonia. It is also widely agreed that if rumen ammonia is to be efficiently used for synthesis of microbial protein (and also if wasteful oxidative deamination of simple nitrogen compounds to provide energy for the microbial population is to be avoided) the ration must be amply supplied with carbohydrate, starch being the most effective form (Chalmers \& Synge, I 954a). It follows that protein concentrates processed to be easily soluble in rumen fluid are apt to have low nutritive values when fed in high-roughage rations. Values would probably be even lower if the ration contained material quantities of silage, the nitrogenous components of it being particularly prone to deamination (El-Shazly, 1952). As rations utilizing roughage are an objective of British feeding developments it follows that technological developments aimed at by-products with a high proportion of readily soluble nitrogen are contraindicated. 
For non-ruminants the nutritive value of a protein concentrate is measured by its capacity to raise the metabolic availability of the digested protein of the whole ration to the level demanded by the productive state of the animal. This involves meeting requirements for both total and essential amino-acids, and the lower the amount of supplementary protein needed the higher its nutritive value.

\section{Nutritional characteristics of some protein concentrates}

Technological developments, here and abroad, that increase the supply of protein concentrates that are equally suitable for ruminants and non-ruminants are more important to us than those aimed at producing concentrates more suitable for one kind than the other. Protein concentrates generally suitable give greater freedom of choice to buyers.

The following are the more important protein concentrates, to some of which the newer techniques of nutritional evaluation have been applied. More extensive technological information was given earlier (Duckworth, 1955).

Fish by-products. All modern factory methods for making fish and herring meals can yield materials of high nutritive value for non-ruminants, but products of low value have been reported. Flame-drying methods demand care, and dry-rendering should be avoided in processing elasmobranchs. Judged by the moderate rise in the ammonia content of rumen liquor after feeding herring meal made by the cookand-press, flame-drying method this product is suitable for ruminant feeding (Chalmers \& Synge, 1954b; Annison, Chalmers, Marshall \& Synge, 1954).

Herring solubles are inferior to fish meals as protein sources for non-ruminants and must be suspect for ruminants. Blends of herring meal and dried solubles (so-called 'whole' meals) have intermediary values as supplementary protein sources for non-ruminants and, presumably, for ruminants. Blending ratios are uncertain.

Herring-meal production by the alkali-reduction process has ceased. The products were of low value for non-ruminants and suspect for ruminants.

Whale by-products. Whale-meat meals have given variable results in non-ruminant feeding. Produced by vacuum-drying on British factory ships and by flamedrying at a British land station they equal high-quality fish meal. Whale solubles are inferior supplementary proteins for non-ruminants, being about equal to groundnut meal, and reflect processing damage to lysine, cystine, methionine and tryptophan (Carpenter, Ellinger \& Shrimpton, 1955). The value of whale-meat meals for ruminants is not known, but whale solubles must be suspect.

Meat meals. These are known to vary greatly in nutritive value for non-ruminants, partly because of variability in raw material, connective tissue being nutritionally inferior to muscle. The effects of different processing methods and of the recent increase in solvent extraction are not known, but tests of current American products showed high variability as sole protein sources (Wilder, 1955).

Cottonseed meal. Through competition from chemical sources of nitrogen (urea and ammoniated by-products) for ruminant feeding the current American trend in cottonseed processing is the development of machinery to yield meals with low free-gossypol content and high solubility of protein. Such meals compete with 
soya-bean meal in non-ruminant feeding. The correlation between protein solubility and nutritive value is high for meals fed as the sole nitrogen source, but less when fed as a supplementary source (Chang, Couch, Lyman, Hunter, Entwistle, Green, Watts, Pope, Cabell \& Earle, I955). Such meals currently command a premium price, which should accelerate changing to the new technique in the U.S. and elsewhere. Such meals would be suspect for ruminant feeding under British conditions.

Groundnut meals. Groundnuts, like soya beans, contain a trypsin inhibitor (Borchers \& Ackerson, I947) that is diminished on heating (Lord \& Wakelam, r950) which thus improves nutritive value (Cama \& Morton, 1950). Stronger heating failed to improve groundnut meal (Borchers \& Ackerson, 1950), perhaps because benefit from inhibitor destruction was offset by protein damage.

Good nutritive value for non-ruminants seems to be associated with mild processing and high values for saline-soluble protein and for protein sulphur. Such meals, with about $75 \%$ of their nitrogen in saline-soluble form yield wastefully large amounts of ammonia in the rumen (Annison et al. 1954).

Sunflower-seed meal. Little is known of the protein quality of this by-product, beyond a report that a standard Canadian process yielded meals much inferior to experimental meals made at lower temperatures. The values of meals made by contrasting methods for ruminants are unknown.

Soya-bean meal. The spectacular growth of the American soya-bean meal industry resulted from adjusting processing so that the potentially high value of the raw material is realized in the product. Appropriate heat treatment inactivates various antinutritional factors in the raw bean, including a trypsin inhibitor, a haemaglutinin and an appetite-depressing protein. The effects of processing on the nutritive value for ruminants is not known.

Laboratory tests of protein quality. An important and increasing tendency has developed to devise in vitro tests of nutritive value of protein concentrates to facilitate factory control of quality and to assist buyers in grading materials offered to them. Hitherto, work has been most concentrated in developing tests of nutritive value for non-ruminants, but if further research confirms as a generalization for all concentrates that high solubility of protein is prejudicial to its value for ruminants part of the approach to grading techniques is apparent.

\section{SUMMARY}

I. Half the national supply of protein concentrates was imported in 1953 and I 954. In 1955 there was a large increase in supplies, mainly of imported oilseed meals.

2. The kinds and, particularly, the origins of imported concentrates varied greatly over the 3-year period. Little research on the nutritive value and less on local processing methods has been published from most sources of these feedingstuffs.

3. Processing has a profound effect on the nutritive value of protein concentrates and, if inadequately controlled, yields highly variable products. 
4. Only on fish, herring, soya-bean and cottonseed meals has extensive research been done, and then almost entirely from the standpoint of suiting the products to non-ruminant needs.

5. A recent trend has been to process oilseed meals for high solubility of protein. Such materials are contraindicated for ruminants under preferred British feeding systems.

6. Attention is now being given to developing rapid laboratory tests of protein quality. If success is attained an appropriate amendment of the Fertilizer \& Feeding Stuffs Act would give protection against low-value protein concentrates of domestic or imported origin, and thus lead to more efficient compounding of rations.

\section{REFERENCES}

Annison, E. F., Chalmers, M. I., Marshall, S. B. M. \& Synge, R. L. M. (1954). \%. agric. Sci. 44, 270. Borchers, R. \& Ackerson, C. W. (1947). Arch. Biochem. 13, 29 r.

Borchers, R. \& Ackerson, C. W. (1950). F. Nutr. 4I, 339.

Cama, H. R. \& Morton, R. A. (1950). Brit. F. Nutr. 4, 297.

Carpenter, K. J., Ellinger, G. M. \& Shrimpton, D. H. (1955). F. Sci. Fd Agric. 6, 296.

Chalmers, M. I. \& Synge, R. L. M. (1954a). Advanc. Protein Chem. 9, 93.

Chalmers, M. I. \& Synge, R. L. M. (1954b). F. agric. Sci. 44, 263.

Chang, W., Couch, J. R., Lyman, C. M., Hunter, W. L., Entwistle, V. P., Green, W. C., Watts, A. B., Pope, C. W., Cabell, C. A. \& Earle, I. P. (1955). F. Amer. Oil Chem. Soc. 32, 103.

Duckworth, J. (r955). F. Sci. Fd Agric. 6, 240.

El-Shazly, K. (1952). Biochem. F. 5I, 640.

Lord, J. W. \& Wakelam, J. A. (1950). Brit. F. Nutr. 4, I 54.

Wilder, O. H. M. (1955). Circ. Amer. Meat Inst. Foundation, no. 15, p. 66. 